\title{
MULTI-CRITERIA ASSESSMENT OF THE SEISMIC VULNERABILITY OF SCHOOL UNITS IN VASLUI CITY, ROMANIA
}

\author{
ANDRA-COSMINA ALBULESCU*, DANIELA LARION ${ }^{\dagger} \&$ ADRIAN GROZAVU \\ Department of Geography, Faculty of Geography and Geology, \\ "Alexandru Ioan Cuza" University of Iași, Romania
}

\begin{abstract}
In the context of an earthquake impact, school units are particularly vulnerable because of the specific age group of the population that studies there. This means that the earthquake mitigation strategies targeting schools should be carefully elaborated, starting from a proper assessment of their seismic vulnerability. Such assessments should be extensively conducted, especially in the case of urban settlements that are disadvantaged in terms of economic potential, social development and media image, like Vaslui City, Romania. This paper aims to evaluate the seismic vulnerability of school units in Vaslui City using a combination of Multi-Criteria Decision-Making (MCDM) methods and Geographic Information System (GIS) techniques. Unlike other assessments of this type, the proposed framework integrates both aspects related to the physical vulnerability of the school buildings, and social elements concerning the educational personnel, the age profile of the pupils, school hours and other factors. The methodology also includes a systemic vulnerability component that offers better insights about the access emergency services would have to the educational institutions in case of a powerful earthquake. The physical, social and systemic vulnerability factors/criteria are weighed via Analytic Hierarchy Process (AHP), while the 25 school units in the study area are evaluated using Weighted Product Model (WPM). The results are combined with GIS techniques in order to obtain a map that shows the seismic vulnerability level of the school units. The most vulnerable school units are the ones with tall old buildings located along narrow streets, with significant number of very young or disabled pupils. These findings represent the stepping stones for the retrofitting works and the educational programmes related to seismic hazards that should be implemented by local authorities. Although restricted by the low number of educational institutions in the study area, the proposed framework may be further on used in seismic vulnerability research.
\end{abstract}

Keywords: seismic vulnerability, school seismic safety, Analytic Hierarchy Process, Vaslui City.

\section{INTRODUCTION}

Vulnerability relates to the dimension of the potential loss inflicted on certain elements at risk by a hazard of a given intensity [1]. Ergo seismic vulnerability represents the degree of loss suffered by human communities and their assets as a consequence of earthquake occurrence. When considering the impact of seismic events, school units emerge as particularly vulnerable public institutions, as they concentrate a high number of young population that needs special care and coordination in case of emergency. The importance of developing seismic hazard mitigation strategies that aim to reduce the vulnerability of school units is underlined by Sendai Framework for Disaster Risk Reduction 2015-2030, where the fourth global target is defined as "Substantially reduce disaster damage to critical infrastructure and disruption of basic services, among them health and educational facilities, including through developing their resilience by 2030" [2]. Complementary, Petal et al. [3] make a strong case for school seismic safety, providing not only an overview of the

*ORCID: https://orcid.org/0000-0002-2315-4729

†ORCID: https://orcid.org/0000-0002-0394-0378 
earthquakes that affected schools and children learning in them in the past decades, but also overviews of global experiences in seismic-resistant school constructions and of global experiences in school seismic retrofit. The paper concludes that "the threat of earthquake damage to school buildings has not been sufficiently well appreciated" [3].

Previous studies of seismic vulnerability of educational institutions follow one of two directions (i) evaluating the damages determined by specific earthquakes [4], [5]; or (ii) estimating the possible damages that may be caused by a future seismic event [6]-[15]. Also, there is an extended scientific literature volume regarding the matter of retrofitting of school buildings [16]-[22].

Seismic vulnerability assessments of schools or loss studies tend to focus on the physical component, taking into account the damage that may occur or that has already occurred at the level of structural and/or non-structural elements [4], [5], [9], [12], [21], [23]. This tendency may be linked to OECD's concern that the collapse of school buildings from around the world is caused by human induced failures, like avoidable construction and design errors, improper use of technology and lack of regulations enforcement [24], [25]. Some of the previous studies use methodologies adapted to fit the evaluation of seismic vulnerability of school buildings made out of a specific construction material [6], [10], [11], while others assess prototypes of school [5], [13], [14], [18]. For many of the mentioned papers, the key element is represented by fragility curves [6], [12], [15], [18] and the number of multicriteria-based approaches to the matter is rather low [23].

This paper aims to assess the seismic vulnerability of school units in Vaslui City, Romania by using a multi-criteria and Geographic Information System (GIS) based approach. The framework combines two classical Multi-Criteria Decision-Making (MCDM) methods in order to evaluate the seismic vulnerability of 25 school units considering factors/criteria related to their physical, social and systemic vulnerability. This approach stands out among the case studies developed hitherto, as it includes not only particular building elements, as most of the studies do, but also aspects concerning the social profile of the educational institutions and their accessibility in emergency situations.

\section{STUDY AREA}

Vaslui City is the administrative centre of the county with the same name, located in the eastern part of Romania, in the Moldavian Plateau, a geotectonic platform unit consisting of sedimentary deposits (especially marl, clays and sandstone) of Sarmatian age (Fig. 1) [26], [27]. The city lies close to the confluence of the Vaslui and Bârlad Rivers, its urban area extending on their floodplain and fluvial terraces. Vaslui City is also the main economic centre of Vaslui County, one of the least developed in Romania, counting a total population of only 55,407 inhabitants in 2011 [28]. Intermediate depth earthquake originating from Vrancea Seismic Zone may impact Vaslui City in significant ways, the peak ground acceleration (ag) for its area being $0.30 \mathrm{~g}$ for a 225 -year average recurrence interval and the spectral displacement (Tc) being 0.7 [29]. The 7.2 MW earthquake in 1977, one of the most feared, officially caused two deaths, numerous injuries and the destruction of several buildings owned by the Jewish community. The exact value of the damages is unknown, due to the fact that the communist regime that was in place at that time misinformed about the aftermath.

There are 25 large school units in Vaslui City, and the total number of the educational institutions that operate underneath their command is 39 . Of these, some are located in the rural settlements around the city, meaning that they do not make the object of the current seismic assessment. Most of them are primary schools combined with gymnasia school units 


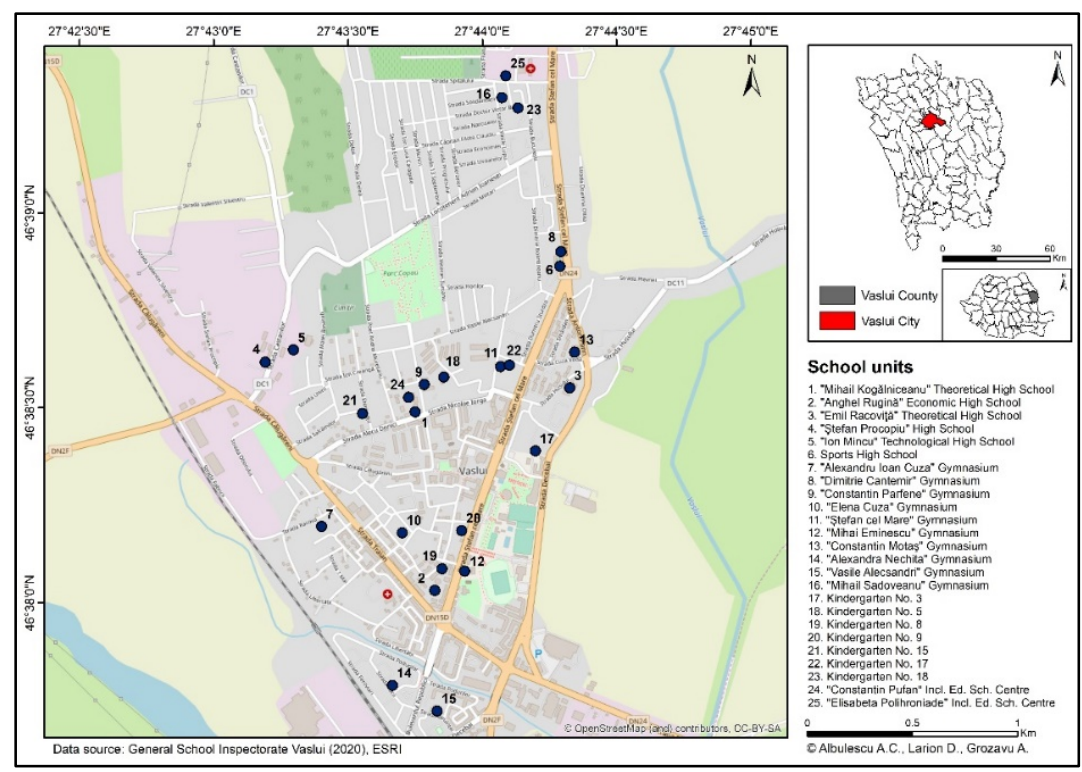

Figure 1: The location of the school units in Vaslui City, Romania.

(10) or kindergartens (7), but there are also five high schools and one high school that also includes a gymnasium. The list is completed by two inclusive education centres that work as educational facilities designated to children with disabilities.

\section{METHODOLOGY}

The factors that are used to assess the seismic vulnerability of the school units in the study area are divided into three categories that complement each other (Fig. 2). They may be regarded as benefit ones, when higher values indicate a higher level of seismic vulnerability, or as non-benefit factors, when higher values lead to opposite levels of vulnerability. A short description of these criteria is provided in Table 1, while the alternatives regarding the criteria are shown in Fig. 3.

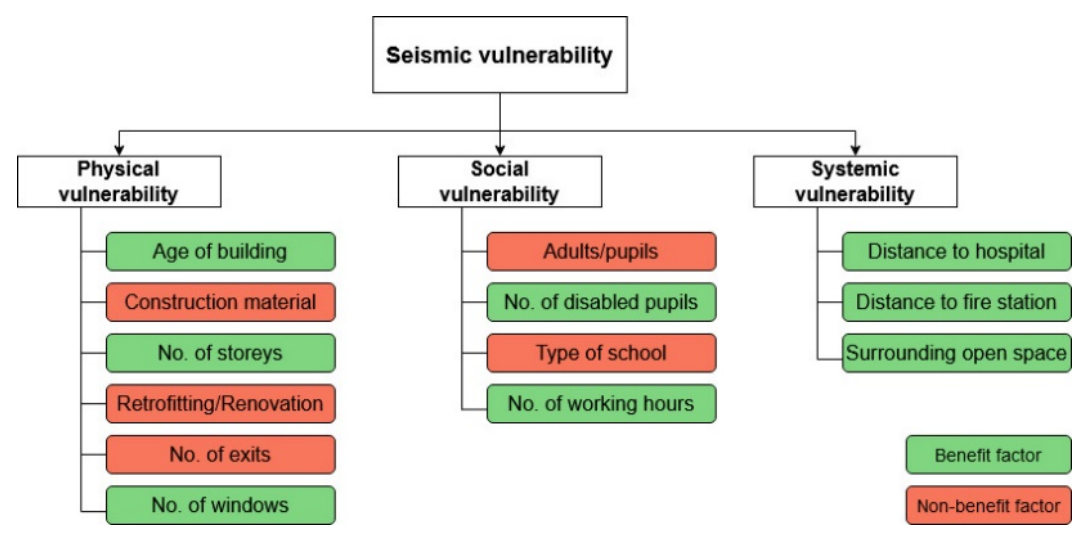

Figure 2: The physical, social and systemic vulnerability factors. 
Table 1: Physical, social and systemic vulnerability factors.

\begin{tabular}{|c|c|c|}
\hline Factor (ACRONYM) & Short description & $\begin{array}{c}\text { Data } \\
\text { source }\end{array}$ \\
\hline $\begin{array}{l}\text { Age of the building } \\
\text { (AGE_B) }\end{array}$ & $\begin{array}{l}\text { Older buildings tend to have suffered more damage } \\
\text { and therefore are more vulnerable to earthquakes' } \\
\text { impact. }\end{array}$ & I \\
\hline $\begin{array}{l}\text { Construction material } \\
\text { (MAT) }\end{array}$ & $\begin{array}{l}\text { Buildings made of concrete and masonry are } \\
\text { considered less resistant to seismic shakes than the } \\
\text { ones that are made of reinforced concrete. }\end{array}$ & $\mathrm{I}, \mathrm{FO}$ \\
\hline $\begin{array}{l}\text { No. of storeys } \\
\text { (STOREYS) }\end{array}$ & $\begin{array}{l}\text { Taller buildings tend to undergo more material } \\
\text { damage and determine higher human tolls than low } \\
\text { height profile ones. }\end{array}$ & $\mathrm{I}, \mathrm{FO}$ \\
\hline $\begin{array}{l}\text { Retrofitting/renovation } \\
(\mathrm{R} \text { R) }\end{array}$ & $\begin{array}{l}\text { It shows weather or not the building recently } \\
\text { underwent retrofitting and/or renovation works. }\end{array}$ & I \\
\hline No. of exits (EXITS) & $\begin{array}{l}\text { The more exits a building has, the easier it is to } \\
\text { channel the evacuation flow towards safety. }\end{array}$ & $\mathrm{I}, \mathrm{FO}$ \\
\hline $\begin{array}{l}\text { No. of windows } \\
\text { (WINDOWS) }\end{array}$ & $\begin{array}{l}\text { The more windows a building has, the higher is the } \\
\text { potential for glass inflicted wounds occurrence. }\end{array}$ & I, FO \\
\hline Adults/pupils (A_P) & $\begin{array}{l}\text { Higher adults/pupils ratios indicate lower } \\
\text { vulnerability levels, as there are more teachers and } \\
\text { auxiliary personnel that supervise and take care of } \\
\text { pupils. }\end{array}$ & I \\
\hline $\begin{array}{l}\text { No. of disabled pupils } \\
\text { (DISABLED_P) }\end{array}$ & $\begin{array}{l}\text { Disabled pupils require special care during } \\
\text { emergency situations because they are less able to } \\
\text { help themselves and others. }\end{array}$ & I \\
\hline $\begin{array}{l}\text { Type of school } \\
\text { (SCH_TYPE) }\end{array}$ & $\begin{array}{l}\text { The age profile of the pupils significantly influences } \\
\text { their ability to properly react in emergency } \\
\text { situations. }\end{array}$ & I \\
\hline $\begin{array}{l}\text { No. of working hours } \\
\text { (WORKING_H) }\end{array}$ & $\begin{array}{l}\text { The longer the working hours of a school unit, the } \\
\text { more likely it is that it will be impacted by an } \\
\text { earthquake. Time periods (morning, noon, evening) } \\
\text { are not considered relevant because of the random } \\
\text { timing of seismic events. }\end{array}$ & I \\
\hline $\begin{array}{l}\text { Distance to hospital } \\
\text { (DIST_H) }\end{array}$ & $\begin{array}{l}\text { It shows the distance to the closest hospital or } \\
\text { ambulance station. The longer the distance, the } \\
\text { higher the overall vulnerability of the school unit. }\end{array}$ & GIS \\
\hline $\begin{array}{l}\text { Distance to fire station } \\
\text { (DIST_FS) }\end{array}$ & $\begin{array}{l}\text { It shows the distance to the closest fire station. The } \\
\text { longer the distance, the harder it is for firefighters to } \\
\text { intervene in case of earthquake determined fires. }\end{array}$ & GIS \\
\hline $\begin{array}{l}\text { Surrounding open } \\
\text { space (OPEN SP) }\end{array}$ & $\begin{array}{l}\text { School units that are located along narrow streets are } \\
\text { less accessible to emergency intervention vehicles. }\end{array}$ & FO \\
\hline
\end{tabular}

GIS = GIS (network analysis), FO = Field observation, I = Interviews. 

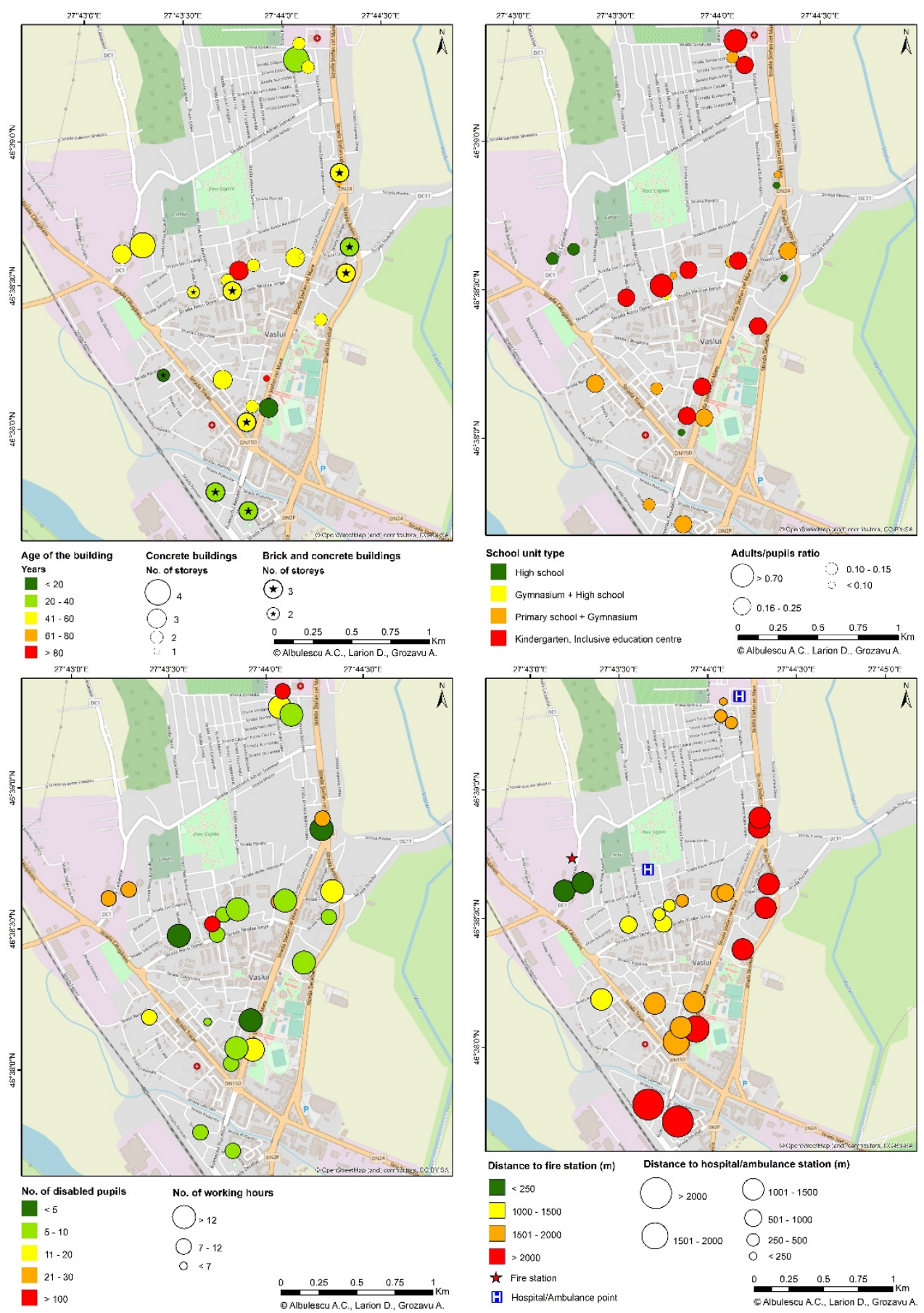

Figure 3: Overview of the school units in Vaslui City. 
Updated data concerning the aforementioned factors were collected from the General School Inspectorate of Vaslui City and the leadership structures of the schools. In February 2020, short interviews with the headmasters and teachers of the school units were conducted in order to obtain a more comprehensive view on the matter. Physical and systemic vulnerability data were collected via GIS techniques and field observation. Other factors that would have been useful for the assessments were the teaching of a hazard protection related subject and the practice of evacuation procedures with the pupils, teaching and auxiliary staff. Because all the school units performed evacuation exercises and none of them had such subjects in the curriculum, the factors did not qualify as relevant.

The factors were weighed via AHP, a MCDM method developed by Saaty in the 1980s [30]-[34], that has been increasingly used in seismic vulnerability related analyses [23], [35][40]. This hierarchical method compares the elements on the same level in pairs, the results being expressed by a number from 1 to 9 according to a predefined scale of absolute numbers and their reciprocals (Table 2). The results of the pairwise comparisons of the factors are organised into a matrix of $\mathrm{m} \times \mathrm{m}$ factors that will be normalized and used to compute the eigenvector. This vector is represented by the arithmetic average of each line in the normalized matrix and illustrates the relative importance of the factors. The method allows for consistency checking of the judgements, which was applied in order to ensure the validity of the factors' weights.

Table 2: The fundamental scale of absolute numbers (after [34]).

\begin{tabular}{|c|l|}
\hline Intensity of importance & Definition \\
\hline 1 & Equal importance \\
\hline 3 & Moderate importance \\
\hline 5 & Strong importance \\
\hline 7 & Very strong or demonstrated importance \\
\hline 9 & Extreme importance \\
\hline $2,4,6,8$ & Intermediate values \\
\hline
\end{tabular}

Each of the three categories of factors was attributed a predefined weight that in order to regulate the weights of the factors by multiplication. Thus, physical vulnerability accounts for $50 \%$ of the total seismic vulnerability, while social vulnerability and systemic vulnerability have relative importance values of $30 \%$, respectively $20 \%$.

Physical vulnerability was considered the most important because the school building may be possibly damaged by powerful earthquakes, inflicting harm on the people. Social vulnerability was given a higher importance then systemic vulnerability due to a higher number of considered factors and to the fact that systemic vulnerability factors do not account for all the relevant accessibility relevant aspects.

Tables 3-5 illustrate the pairwise comparisons of the factors in the three categories. The pairwise comparisons judgements were made considering information provided by scientific literature and obtained from the interviews with the personnel of the evaluated school units, as well as the judgements of the authors.

Further on, the results of the AHP were integrated in WPM in order to compute the final scores of the alternatives. This method is a derivate of the Weighted Sum Model that allows the use of different measuring units for the alternatives' scores concerning their performance to particular factors [41]. This paper uses the alternative approach of the WPM, where the ratios are excluded, and the final scores of the alternatives are computed by eqn (1), where $S\left(A_{K}\right)$ is the score of the $K$ th alternative, $n$ is the number of factors and $W$ is the eigenvector: 
Table 3: Pairwise comparisons matrix of the physical vulnerability factors.

\begin{tabular}{|l|c|c|c|c|c|c|}
\hline & AGE_B & MAT & STOREYS & R_R & EXITS & WINDOWS \\
\hline AGE_B & 1 & 2 & 3 & 3 & 4 & 4 \\
\hline MAT & 0.50 & 1 & 4 & 3 & 4 & 4 \\
\hline STOREYS & 0.33 & 0.25 & 1 & 0.33 & 3 & 3 \\
\hline R_R & 0.33 & 0.33 & 3 & 1 & 3 & 3 \\
\hline EXITS & 0.25 & 0.25 & 0.33 & 0.33 & 1 & 1 \\
\hline WINDOWS & 0.25 & 0.25 & 0.33 & 0.33 & 1 & 1 \\
\hline
\end{tabular}

Table 4: Pairwise comparisons matrix of the social vulnerability factors.

\begin{tabular}{|l|c|c|c|c|}
\hline & A_P & DISABLED_P & SCH_TYPE & WORKING_H \\
\hline A_P & 1 & 0.33 & 0.25 & 3 \\
\hline DISABLED_P & 3 & 1 & 1 & 3 \\
\hline SCH_TYPE & 4 & 1 & 1 & 4 \\
\hline WORKING_H & 0.33 & 0.33 & 0.25 & 1 \\
\hline
\end{tabular}

Table 5: Pairwise comparisons matrix of the systemic vulnerability factors.

\begin{tabular}{|l|c|c|c|}
\hline & DIST_H & DIST_FS & OPEN_SP \\
\hline DIST_H & 1 & 2 & 0.33 \\
\hline DIST_FS & 0.50 & 1 & 0.33 \\
\hline OPEN_SP & 3 & 3 & 1 \\
\hline
\end{tabular}

$$
S\left(A_{K}\right)=\prod_{i=1}^{n}\left(A_{K i}\right)^{W_{i}} .
$$

Larger values of the WPM score indicate higher levels of seismic vulnerability, meaning that the school units with the lowest scores are the least expected to be damaged following a powerful earthquake. The scores obtained by the school units in the study area were classified according to an arithmetic progression into five seismic vulnerability classes: very low, low, medium, high and very high.

\section{RESULTS}

Calibrating the weights of the factors with the ones of the commanding category, the following relative importance values were obtained (Table 6). For each of the matrices, the consistency ratio was lower than 0.1 , which confirms the validity of the judgements. In terms of physical vulnerability, the most important factor was the age of the building, which prevails over the construction material, as time has different effects on certain materials. The retrofitting/renovation works factor had a slightly lower score than the other two factors, its importance being highlighted by the influence it has on the capacity of school buildings to withstand seismic shakes. The number of storeys ranked before the number of exits and windows, which were given equal importance, because both the easiness of evacuation due to a higher number of exits and the harm inflicted by shattered glass are volatile scenarios.

The type of school unit was the most important social vulnerability factor, directly relating to the age of the pupils that determines the amount of care and coordination adults have to provide in emergency situations. Also, the number of disabled pupils was of high importance, ranking before the adults/pupils ratio that may or may not be relevant, depending on the 
Table 6: The weights of the physical, social and systemic vulnerability factors.

\begin{tabular}{|l|c|c|c|c|}
\hline & $\begin{array}{c}\text { Weights in } \\
\text { category }\end{array}$ & $\begin{array}{c}\text { Weights } \\
\mathbf{( \% )}\end{array}$ & $\begin{array}{c}\text { Final } \\
\text { weight }\end{array}$ & $\begin{array}{c}\text { Final } \\
\text { weight (\%) }\end{array}$ \\
\cline { 1 - 2 } Physical vulnerability factors & $\mathbf{0 . 5}$ & $\mathbf{5 0}$ & & 16.64 \\
\hline AGE_B & 0.3328 & 33.28 & 0.1664 & 13.75 \\
\hline MAT & 0.2750 & 27.50 & 0.1375 & 5.74 \\
\hline STOREYS & 0.1147 & 11.47 & 0.0574 & 8.03 \\
\hline R_R & 0.1606 & 16.06 & 0.0803 & 2.92 \\
\hline EXITS & 0.0583 & 5.83 & 0.0292 & 2.92 \\
\hline WINDOS & 0.0583 & 5.83 & 0.0292 & \\
\hline Social vulnerability factors & $\mathbf{0 . 3}$ & $\mathbf{3 0}$ & & \\
\hline A_P & 0.1544 & 15.44 & 0.0463 & 4.63 \\
\hline DISABLED_P & 0.3519 & 35.19 & 0.1056 & 10.56 \\
\hline SCH_TYPE & 0.4046 & 40.46 & 0.1214 & 12.14 \\
\hline WORKING_G & 0.0889 & 8.89 & 0.0267 & 2.67 \\
\hline Systemic vulnerability factors & $\mathbf{0 . 2}$ & $\mathbf{2 0}$ & & \\
\hline DIST_H & 0.2518 & 25.18 & 0.0504 & 5.04 \\
\hline DIST_FS & 0.1592 & 15.92 & 0.0319 & 3.19 \\
\hline OPEN_SP & 0.5888 & 58.88 & 0.1178 & 11.78 \\
\hline
\end{tabular}

different age groups of the pupils and considering that earthquake induced panic may affect responsible adults. Then number of working hours was considered the least important because the time of earthquake occurrence is unknown. However, the longer the schedule of a school unit, the higher the chances of its human community of being affected by an earthquake when performing educational activities.

The open space that surrounds school units is essential for the access of ambulances, fire fighters' vehicles and other automobiles, fact that explains its prevailing importance. Also, the need for medical interventions in case of a powerful earthquake is more significant than the necessity of fire fighters' interventions, because the development of fires is less frequent than the incidence of common injuries caused by earthquakes.

Both of the ends of the seismic vulnerability spectrum (very low, respectively very high) include two school units, while the category with the most numerous elements (nine schools) is the one of high seismic vulnerability. There are eight schools with medium seismic vulnerability and four with a low level of this parameter.

Fig. 4 indicates that the two school units with the highest seismic vulnerability were the inclusive education centres in Vaslui City, which is explained by the very profile of these institutions that provide care and educational services exclusively to children with disabilities. These were followed by a series of primary school and gymnasiums facilities and kindergartens that tend to cluster along a line that follows an E-W direction in the central part of the city. Some of the shared features of the schools with high seismic vulnerability consist of old or very old buildings with two or three storeys, a high number of windows and generally low ratios of adults/pupils.

Medium seismic vulnerability school units tend to follow the same central line, with few exceptions and are also represented by gymnasia and kindergartens. The high schools that fit into this category are "Ștefan Procopiu" High School, "Ion Mincu" Technological High School and "Mihail Kogălniceanu" Theoretical High School. The latter is the most 


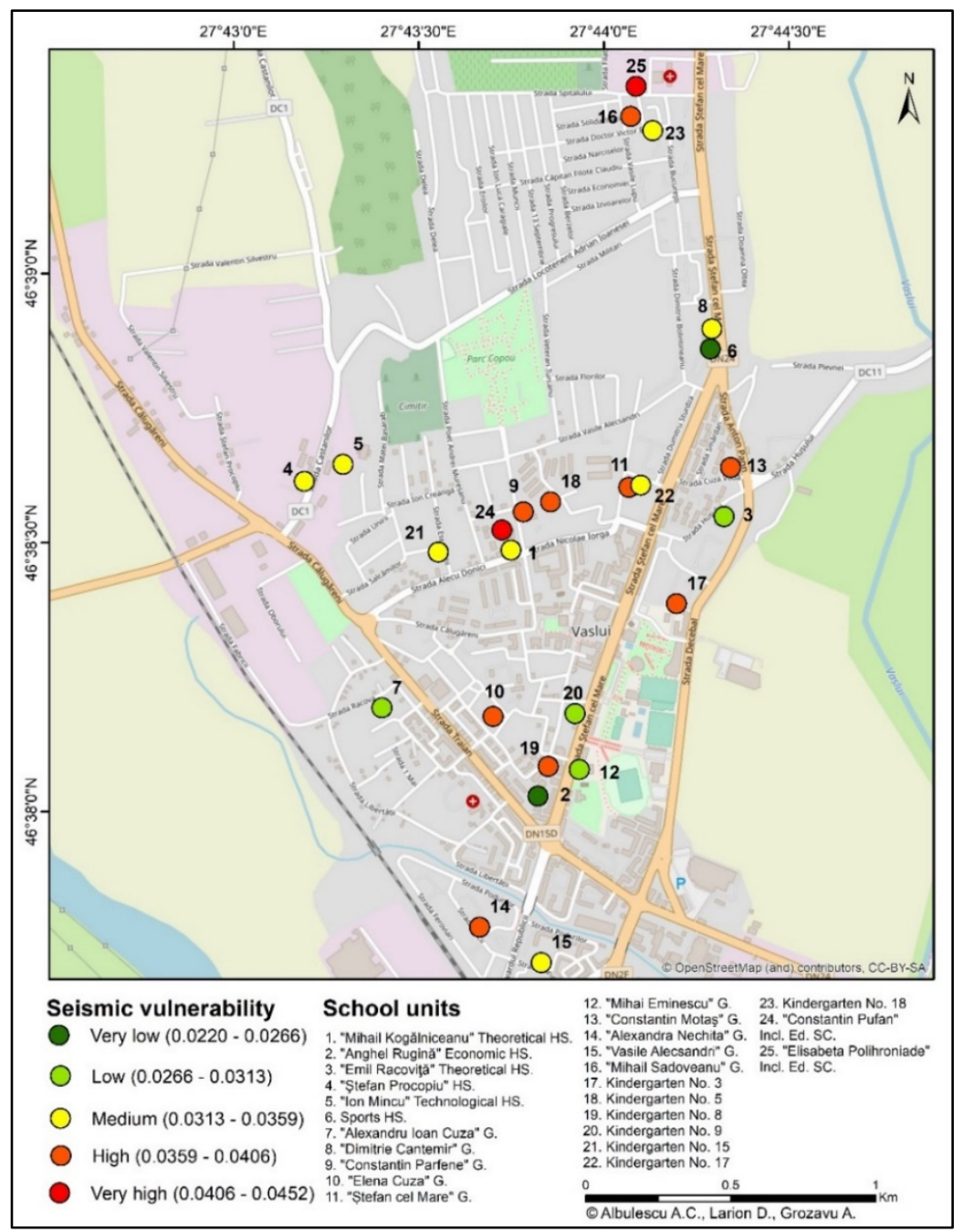

Figure 4: The seismic vulnerability of school units in Vaslui City.

performant educational institution in Vaslui City and its medium seismic vulnerability is motivated by the facts that it also encompasses classes of gymnasia, its building is rather old, it has a very low adults/pupils ratio and its height profile corresponds to significant levels of physical seismic vulnerability.

The school units with low or very low levels of seismic vulnerability were primary schools combined with gymnasia, and high schools that are aligned along main streets (Ștefan cel Mare and Traian Streets). Obviously, pupils of higher ages are better equipped to deal with emergency situations from psychological and physical points of view. The only exception was Kindergarten No. 9, for which its one-storey concrete building sufficient number of exits, recent retrofitting works, very low number of disabled pupils, high adults/pupils ratio and extended surrounding space, despite its old building, accounts for its low seismic vulnerability. 
Sports High School obtained the best score concerning the capacity to withstand the impact of an earthquake. This is because the aforementioned educational institution does not accept disabled pupils, its concrete building has only one storey, a significant number of exits and was recently renovated. In addition, Sports High School lies close to a major road intersection of the city, which allows for effective emergency services interventions.

\section{CONCLUSIONS}

School seismic safety is one of the most important aspects of seismic hazard mitigation, numerous international decisional factors and scholars stressing its importance. Without proper, comprehensive vulnerability assessments, preventive measures and planning instruments that aim to reduce risks cannot be efficiently elaborated and implemented.

Most of the school units in Vaslui City have high levels of seismic vulnerability, correlated with young ages of the pupils that attend them, old buildings with more than three storeys, the absence of retrofitting/renovation works, low ratios of adults/pupils, a high number of disabled pupils or low accessibility. These school units are located mainly in the centre, the northern and southern areas of the city. On the contrary, the school units with older pupils, lower height profiles and lower numbers of disabled pupils tend to score better in the matter of withstanding the impact of earthquakes. The educational facilities with very low or low seismic vulnerability are located along the main streets, benefiting from high accessibility.

For small and medium-size urban centres that are disadvantaged from social and economic points of view, like Vaslui City, such assessments and the implementation of deriving seismic hazard mitigation strategies may prove to significantly influence the aftermath of earthquakes. The framework of this paper may be applied to other study areas, serving as another example of how MCDM methods may be integrated with GIS techniques in order to estimate the seismic vulnerability of educational institutions not only from a physical vulnerability perspective, but also including social and systemic vulnerability elements.

\section{ACKNOWLEDGEMENT}

This work was co-funded by the European Social Fund, through Operational Programme Human Capital 2014-2020, project no. POCU/380/6/13/123623.

\section{REFERENCES}

[1] Coburn, A.W., Spence, R.J.S. \& Pomonis, A., Vulnerability and risk assessment. United Nations Development Programme, Disaster Management Training Programme, 69 pp., 1994.

[2] UNISDR (United Nations International Strategy for Disaster Reduction), Sendai Framework for Disaster Risk Reduction 2015-2030, UNISDR: Geneva, 37 pp., 2015.

[3] Petal, M. et al., School seismic safety and risk mitigation. Encyclopedia of Earthquake Engineering, pp. 2450-2468, 2015.

[4] Augenti, N., Cosenza, E., Dolce, M., Manfredi, G., Masi, A. \& Samela, L., Performance of school buildings during the 2002 Molise, Italy, earthquake. Earthquake Spectra, 20(S1), pp. S257-S270, 2004.

[5] Di Ludovico, M., Digrisolo, A., Moroni, C., Graziotti, F., Manfredi, V., Prota, A., Dolce, M. \& Manfredi, G., Remarks on damage and response of school buildings after the central Italy earthquake sequence. Bulletin of Earthquake Engineering, 17(10), pp. 5679-5700, 2019.

[6] Azizi-Bondarabadi, H., Mendes, N., Lourenço, P.B. \& Sadeghi, N.H., Empirical seismic vulnerability analysis for masonry buildings based on school buildings survey in Iran. Bulletin of Earthquake Engineering, 14(11), pp. 3195-3229, 2016. 
[7] Baballëku, M. \& Pojani, N., Fragility evaluation of existing typified school buildings in Albania. Acta Geodaetica et Geophysica Hungarica, 43(2-3), pp. 309-325, 2008.

[8] Clementi, F., Quagliarini, E., Maracchini, G. \& Lenci, S., Post-World War II Italian school buildings: Typical and specific seismic vulnerabilities. Journal of Building Engineering, 4, pp. 152-166, 2015.

[9] De Angelis, A. \& Pecce, M., Seismic nonstructural vulnerability assessment in school buildings. Natural Hazards, 79(2), pp. 1333-1358, 2015.

[10] Giordano, N., De Luca, F. \& Sextos, A., Out-of-plane closed-form solution for the seismic assessment of unreinforced masonry schools in Nepal. Engineering Structures, 203, 109548, 2020.

[11] Korkmaz, M., Ozdemir, M.A., Kavali, E. \& Cakir, F., Performance-based assessment of multi-story unreinforced masonry buildings: The case of historical Khatib School in Erzurum, Turkey. Engineering Failure Analysis, 94, pp. 195-213, 2018.

[12] Michel, C., Hannewald, P., Lestuzzi, P., Fäh, D. \& Husen, S., Probabilistic mechanicsbased loss scenarios for school buildings in Basel (Switzerland). Bulletin of Earthquake Engineering, 15(4), pp. 1471-1496, 2017.

[13] O’Reilly, G.J., Perrone, D., Fox, M., Monteiro, R. \& Filiatrault, A., Seismic assessment and loss estimation of existing school buildings in Italy. Engineering Structures, 168, pp. 142-162, 2018.

[14] Rodrigues, H., Furtado, A., Vila-Pouca, N., Varum, H. \& Barbosa, A.R., Seismic assessment of a school building in Nepal and analysis of retrofitting solutions. International Journal of Civil Engineering, 16(11), pp. 1573-1589, 2018.

[15] Zain, M., Usman, M., Farooq, S.H. \& Mehmood, T., Seismic vulnerability assessment of school buildings in seismic zone 4 of Pakistan. Advances in Civil Engineering, 1, pp. 1-14, 2019.

[16] Anelli, A., Santa-Cruz, S., Vona, M., Tarque, N. \& Laterza, M., A proactive and resilient seismic risk mitigation strategy for existing school buildings. Structure and Infrastructure Engineering, 15(2), pp. 137-151, 2019.

[17] Casciati, F. \& Casciati, S., Amelioration and retrofitting of educational buildings. Earthquake Engineering and Engineering Vibration, 17(1), pp. 47-51, 2018.

[18] Chrysostomou, C.Z., Kyriakides, N., Papanikolaou, V.K., Kappos, A.J., Dimitrakopoulos, E.G. \& Giouvanidis, A.I., Vulnerability assessment and feasibility analysis of seismic strengthening of school buildings. Bulletin of Earthquake Engineering, 13(12), pp. 3809-3840, 2015.

[19] Grant, D.N., Bommer, J.J., Pinho, R., Calvi, G.M., Goretti, A. \& Meroni, F., A prioritization scheme for seismic intervention in school buildings in Italy. Earthquake Spectra, 23(2), pp. 291-314, 2007.

[20] Guo, T., Xu, W., Song, L. \& Wei, L., Seismic-isolation retrofits of school buildings: Practice in China after recent devastating earthquakes. Journal of Performance of Constructed Facilities, 28(1), pp. 96-107, 2014.

[21] Jaimes, M.A. \& Nino, M., Cost-benefit analysis to assess seismic mitigation options in Mexican public school buildings. Bulletin of Earthquake Engineering, 15(9), pp. 3919-3942, 2017.

[22] Naja, M.K. \& Baytiyeh, H., Towards safer public school buildings in Lebanon: An advocacy for seismic retrofitting initiative. International Journal of Disaster Risk Reduction, 8, pp. 158-165, 2014.

[23] Panahi, M., Rezaie, F. \& Meshkani, S.A., Seismic vulnerability assessment of school buildings in Tehran city based on AHP and GIS. Natural Hazards and Earth System Sciences, 14(4), pp. 969-979, 2014. 
[24] Dixit, A.M., Acharya, S.P., Shrestha, S.N. \& Dhungel, R., How to render schools safe in developing countries? Earthquake Hazard, Risk and Disasters, ed. M. Wyss, pp. 183-202, Academic Press: London, 2014.

[25] OECD (Organisation for Economic Co-operation and Development), Keeping schools safe in earthquakes: A publication of the OECD Programme on Educational Building (PEB), OECD Publishing: Paris, 244 pp., 2004.

[26] Băcăuanu, V., Barbu, N., Pantazică, M., Ungureanu, A. \& Chiriac, D. (eds), Podişul Moldovei. Natură, om, economie [The Moldavian Plateau: Nature, Human, Economy], Editura Științifică și Enciclopedică: Bucharest, 183 pp., 1980.

[27] Răţoi, B.G. \& Brânzilă, M., Sedimentological study of the Khersonian deposits from Paiu and Monument open pits (Vaslui City): Preliminary Data. Studii și cercetări. Geology-Geography, 17, pp. 71-79, 2012.

[28] NIS (National Institute of Statistics), The National Census. www.recensamantromania.ro/rezultate-2/. Accessed on: 3 Mar. 2020.

[29] Code O100-1/2013. Seismic Design Code: Part 1 - Provisions for the design of buildings. Indicative P-100/1. Elaborated by UTCB, Endorsed by MDRAP, Official Journal of Romania: Bucharest, 925 pp., 2013.

[30] Saaty, T.L., A scaling method for priorities in hierarchical structures. Journal of Mathematical Psychology, 15(3), pp. 234-281, 1977.

[31] Saaty, T.L., The Analytic Hierarchy Process: Planning, Priority Setting. Resource Allocation, McGraw-Hill: New York, 287 pp., 1980.

[32] Saaty, T.L., The analytic hierarchy process: What it is and how it is used. Mathematical Modelling, 9(3-5), pp. 161-176, 1987.

[33] Saaty, T.L., Decision making: The analytic hierarchy and network processes (AHP/ANP). Journal of Systems Science and Systems Engineering, 13(1), pp. 1-35, 2004.

[34] Saaty, T.L., Decision making with the analytic hierarchy process. International Journal of Services Sciences, 1(1), pp. 83-98, 2008.

[35] Albulescu, A.C., Grozavu, A. \& Larion, D., A GIS-based application of fuzzy AHP and classical TOPSIS methods on assessing the seismic vulnerability of Galaţi City, Romania. Proceedings of the International Multidisciplinary Scientific Geoconference SGEM, 19(2.1), pp. 737-744, 2019.

[36] Armaş, I., Multi-criteria vulnerability analysis to earthquake hazard of Bucharest, Romania. Natural Hazards, 63(2), pp. 1129-1156, 2012.

[37] Bănica, A., Rosu, L., Muntele, I. \& Grozavu, A., Towards urban resilience: A multicriteria analysis of seismic vulnerability in Iasi City (Romania). Sustainability, 9(2), pp. 270-237, 2017.

[38] Han, J. \& Kim, J., A GIS-based seismic vulnerability mapping and assessment using AHP: A case study of Gyeongju, Korea. Korean Journal of Remote Sensing, 35(2), pp. 217-228, 2019.

[39] Rashed, T. \& Weeks, J., Assessing vulnerability to earthquake hazards through spatial multicriteria analysis of urban areas. International Journal of Geographical Information Science, 17(6), pp. 547-576, 2003.

[40] Rezaie, F. \& Panahi, M., GIS modeling of seismic vulnerability of residential fabrics considering geotechnical, structural, social and physical distance indicators in Tehran using multi-criteria decision-making techniques. Natural Hazards and Earth System Sciences, 15(3), pp. 461-474, 2015.

[41] Triantaphyllou, E., Multi-Criteria Decision-Making Methods: A Comparative Study, Springer: Boston, MA, 289 pp., 2000. 


\section{SECTION 2 \\ RISK ASSESSMENT \\ AND MANAGEMENT}





\title{
ASSESSING OIL SPILL RISK IN LOWER COOK INLET, ALASKA
}

\author{
ZHEN-GANG JI, CARYN SMITH \& WALTER R. JOHNSON \\ Bureau of Ocean Energy Management, USA
}

\begin{abstract}
The U.S. Federal Government offered for oil and gas leasing a portion of the U.S. Outer Continental Shelf (OCS) lands in Cook Inlet, Alaska (Lease Sale 244). Because oil spills may occur from activities associated with offshore oil and gas exploration, production, decommissioning, and transportation, the U.S. Department of the Interior Bureau of Ocean Energy Management conducts oil spill risk analysis (OSRA) to support National Environmental Policy Act analyses prior to conducting an oil and gas lease sale. The objective of OSRA is to estimate the probability of oil spill occurrence, the probability of oil spill contact, and the probability of oil spill occurrence and contact to sensitive offshore and onshore environmental resources and socioeconomic features from hypothetical oil spills accidentally occurring from OCS oil and gas-related activities. This paper presents the results of OSRA conducted for use in the Cook Inlet OCS Oil and Gas Lease Sale 244 Environmental Impact Statement. The OSRA model estimated oil spill trajectories using model-simulated hindcast fields of winds, sea ice movement and concentration, and surface ocean currents in the Cook Inlet, Shelikof Strait, and Gulf of Alaska. This paper also summarizes stochastic contact patterns and associated risks.
\end{abstract}

Keywords: oil spill, risk analysis, OSRA model, Cook Inlet.

\section{INTRODUCTION}

The U.S. Federal Government offered a portion of the U.S. Outer Continental Shelf (OCS) lands in Cook Inlet, Alaska, for oil and gas leasing (Lease Sale 244, Figs 1 and 2). Because oil spills may occur from activities associated with offshore oil and gas exploration, production, decommissioning, and transportation, the U.S. Department of the Interior (USDOI) Bureau of Ocean Energy Management (BOEM) conducts oil spill risk analysis (OSRA) to support National Environmental Policy Act (NEPA) analyses completed prior to conducting an oil and gas lease sale. This paper summarizes the OSRA data and results used in the Cook Inlet OCS Oil and Gas Lease Sale 244 Environmental Impact Statement (EIS) to estimate the probability of oil spill contact, the probability of oil spill occurrence, and the probability of oil spill occurrence and contact to sensitive offshore and onshore environmental resources and socioeconomic features from oil spills accidentally occurring from OCS oil and gas-related activities.

The occurrence of oil spills is fundamentally a matter of probability. There is no certainty regarding the amount of oil and gas that would be discovered and then produced, or that an oil spill would occur during the estimated life of a given lease sale. Furthermore, the winds, ocean currents, and sea ice that transport oil spills cannot be known for certain. A probabilistic event, such as an oil spill occurrence or oil spill contact to an environmental, social, or economic resource, cannot be predicted, but an estimate of its likelihood (probability) can be quantified.

\section{FRAMEWORK OF THE ANALYSIS}

Many factors are considered when producing an OSRA for a proposed lease sale. These include the study area, the area proposed for leasing (Proposed Action) and its alternatives, the estimated volume of oil and gas resources in the proposed leasing area, and the individual components of the OSRA model. 